\title{
Techno Economic Analysis Photovoltaic On-Grid System Java Bali to Optimize PLN Energy Consumption
}

\author{
Ikhsan Hernanda ${ }^{1}$, Riadhi Fairuz ${ }^{1}$, and Eko Adhi Setiawan ${ }^{* 1,2}$ \\ ${ }^{1}$ Electrical Engineering, Electrical Engineering Department, Universitas Indonesia, Depok, Indonesia \\ ${ }^{2}$ Tropical Renewable Centre, Faculty of Engineering, Universitas Indonesia, Depok, Indonesia
}

\begin{abstract}
Indonesia's electricity needs are increasing along with population growth. Nonrenewable natural resources are insufficient for power generation. Indonesia as a country located on the equator, has $4.8 \mathrm{kWh} / \mathrm{m}^{2} /$ day the potential of solar energy, it is time for expanded renewable energy based photovoltaic. The potential development of photovolitaic system in Java Bali is planned to 800 MW based on Rencana Usaha Penyediaan Tenaga Listrik (RUPTL) year 2018-2027. Photovoltaic system on-grid rooftop $2 \mathrm{kWp}$ designed on the Java Bali residence sector based on income of population, number of customers, power sales, and number of population. The energy produced by photovoltaic on-grid system can save the use of coal fuel in 2019 of 1.07 trillion rupiah and until 2027 can save about 11.08 trillion rupiah. The net metering scheme with $30 \%$ incentive can be applied for photovoltaic on-grid rooftop $2 \mathrm{kWp}$ system. Photovoltaic on-grid system in the residence sector in Java Bali can save electricity payment for $37.9-41 \%$.
\end{abstract}

\section{Introduction}

Indonesia is located in a tropical region having sunlight that can be utilized to build photovoltaic on-grid system. The sun shines from morning to evening with an average daily radiation of $4.80 \mathrm{kWh} / \mathrm{m} 2 /$ day [1]. The photovoltaic on-grid system is a power plant that converts solar thermal energy into electrical energy. One method that can be used is direct way to transfer solar radiation or light energy into electrical energy called photovoltaic.

The Ministry of Energy and Mineral Resources through the Directorate General of Renewable Energy and Energy Conversion has a policy in 2025, the role of renewable energy at least $23 \%$. The potential development of photovoltaic systems in Java Bali has the greatest potential study of $800 \mathrm{MW}$ [2]. Coal fuel need very year has increased, while coal reserves are decreasing. Photovoltaic on-grid system in the household sector can reduce coal fuel need as a source of electrical energy.

\section{Methodologi}

Based on RUPTL in 2017 [2], photovoltaic on-grid system will be developed in state electricity company with the potential of primary energy in each location and consider the distribution of the population on a very wide geography. Java Bali area has a very large capacity as can be seen in Table 1 .
Table 1. Potential of Solar Power

\begin{tabular}{|l|l|}
\hline Territory / distribution / system & $\begin{array}{c}\text { Capacity } \\
\text { MW }\end{array}$ \\
\hline Java Bali & 800 \\
\hline West Kalimantan & 30 \\
\hline East \& North Kalimantan & 50 \\
\hline Suluttenggo & 75 \\
\hline NTB & 55 \\
\hline NTT & 16 \\
\hline Papua & 40 \\
\hline
\end{tabular}

[3]SAM (System Advisor Model) is an application that combines the potential calculation and PV system specifications that have been stored in the SAM database to calculate the production of electricity. The writer choose SAM because free of charge usage. By entering design data system, system cost, electricity tariff and financial parameters, the program will be simulated. Data of simulation result are; LCOE value, Net Present Value (NPV) and Payback Period. In addition, the calculation results can also be presented in graphs, cashflow tables and others. The SAM simulation illustration can be shown in Fig 1. 


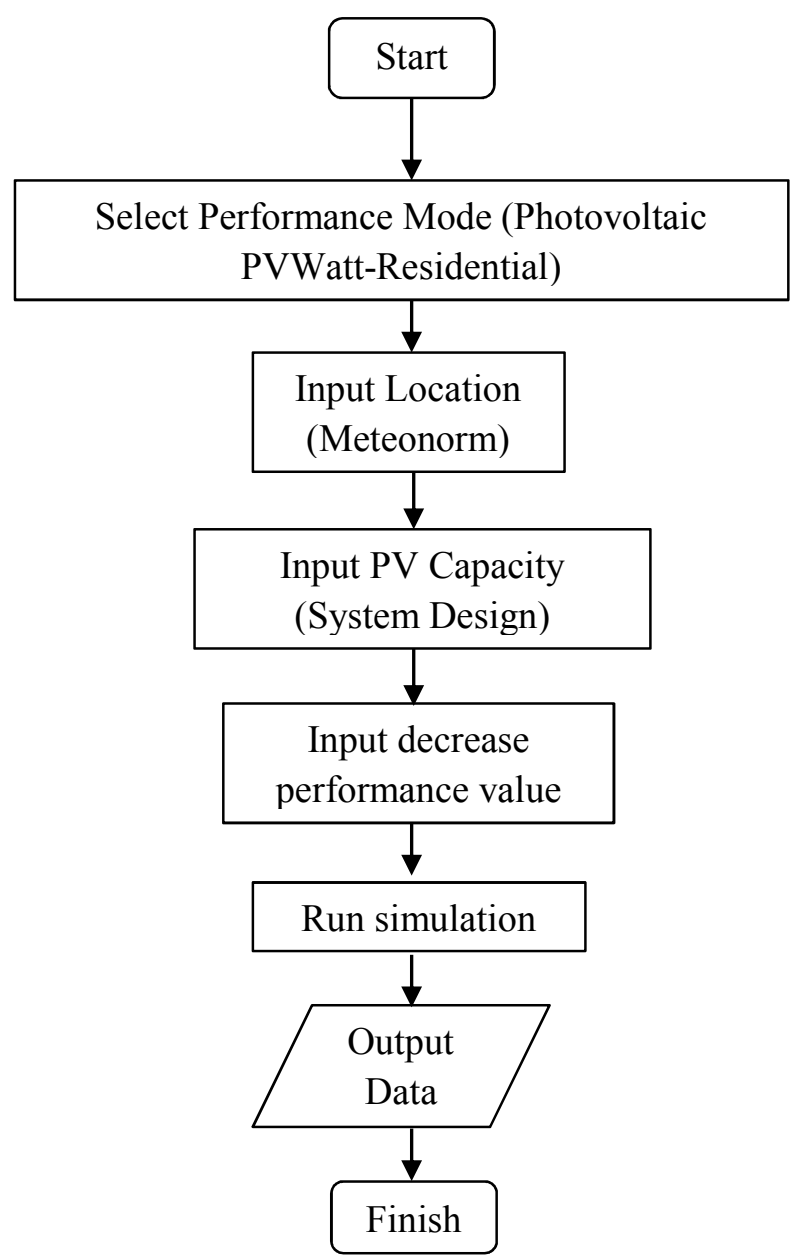

Fig 1. System Advisor Model (SAM) Sceme

[4]Meteonorm were used to determine radiation data by inserting latitude and longitude coordinates. Java-Bali meteonorm data has average radiation and temperature of each city. The average radiation value can be seen at Figure 2.

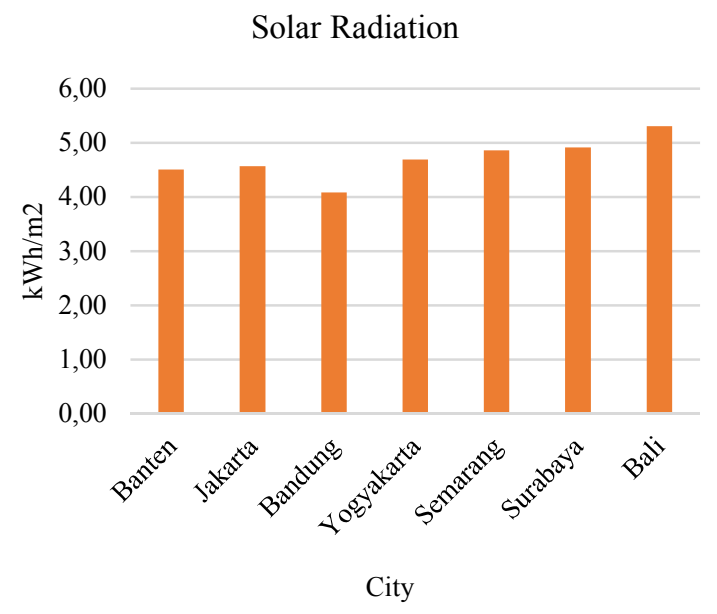

Fig 2. Solar Radiation

Fig 2. The picture above can be seen the largest radiation value in Bali is $5.30 \mathrm{kWh} / \mathrm{m}^{2} /$ day and the smallest in Bandung is $4.08 \mathrm{kWh} / \mathrm{m}^{2} /$ day.

\section{Result and Conclusion}

In the SAM simulation, PLTS-PV Rooftop were designed with a life 20 years with $0.5 \%$ reduction in device performance annually. PLTS-PV $2 \mathrm{kWp}$ produces different energy each year in each region. The energy produced in one year can be seen in Fig 3 .

\section{The Annual Energy of PLTS-PV Rooftop 2kWp}

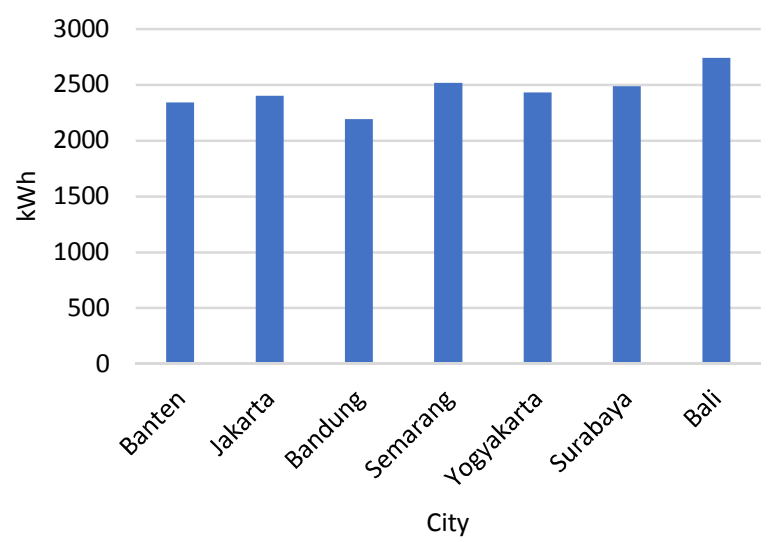

Fig 3. The Annual Energy of PLTS-PV Rooftop $2 \mathrm{kWp}$

Fig 3, the largest energy produced in Bali 2,745 $\mathrm{kWh}$, and Bandung produces the lowest energy of $2,196 \mathrm{kWh}$. Every year there is a decrease of energy $0.5 \%$ due to the degradation of PV device conditions. The difference in energy produced by each region is due to the varying levels of solar radiation.

\subsection{Targeting of PLTS Installation}

\subsubsection{Income of population}

Installation of PLTS-PV Rooftop $2 \mathrm{kWp}$ has a large investment value so it can not be sure all the houses can invest into this PV system. In addition, with different of population income will cause uneven PVRooftop installation. Considering this, the installation of PLTS-PV is determined based on the magnitude of the regional Gross Regional Domestic Product (GRDP) of population area. There was the number of installation and energy produced by PLTS-PV Rooftop which can be seen in Table 2

Tabel 2. PLTS-PV Rooftop $800 \mathrm{MW}$ based on income of population

\begin{tabular}{|l|c|c|c|c|c|}
\hline \multirow{2}{*}{ Province } & \multirow{2}{*}{$\begin{array}{c}\text { Income of } \\
\text { population } \\
\text { (Million Rupiah) }\end{array}$} & \multirow{2}{*}{$\begin{array}{c}\text { Percentage } \\
(\%)\end{array}$} & \multicolumn{3}{|c|}{$\begin{array}{c}\text { PLTS Java-Bali } \\
\text { 800 MW }\end{array}$} \\
\cline { 3 - 6 } & & & MW & Unit & GWh \\
\hline DKI Jakarta & 211,8 & $47,63 \%$ & 381 & 190.537 & 458,24 \\
\hline East Java & 47,5 & $10,68 \%$ & 85 & 42.702 & 106,33 \\
\hline Bali & 46,5 & $10,46 \%$ & 84 & 41.841 & 114,85 \\
\hline Banten & 42,3 & $9,51 \%$ & 76 & 38.058 & 89,21 \\
\hline West Java & 34,9 & $7,84 \%$ & 63 & 31.374 & 68,90 \\
\hline Central Java & 32,1 & $7,22 \%$ & 58 & 28.874 & 72,73 \\
\hline DIY & 29,6 & $6,65 \%$ & 53 & 26.615 & 64,73 \\
\hline
\end{tabular}


Based on the data in Table 2, the largest of population income in DKI Jakarta amounted to 211.8 million rupiah, as much as $47.63 \%$ of the total energy installed at 190,537 homes will produce $458.24 \mathrm{GWh}$ of energy. While the smallest is located in DIY with population income of 29.6 million rupiah, as much as $6.65 \%$ of energy installed in 26,615 homes will produce $64.73 \mathrm{GWh}$ of energy.

\subsubsection{Number of Customers}

Every province in Java-Bali has different population so that the number of electric power cutomers also varies. There was the number of installation and energy produced by PLTS-PV Rooftop based on the number of costumers of each province which can be seen in Table 3.

Table 3. PLTS-PV Rooftop $800 \mathrm{MW}$ based on Customers of Residence

\begin{tabular}{|l|c|c|c|c|c|}
\hline \multirow{2}{*}{ Province } & \multirow{2}{*}{$\begin{array}{c}\text { Costomer } \\
\text { (Million) }\end{array}$} & $\begin{array}{c}\text { Percentage } \\
(\%)\end{array}$ & \multicolumn{3}{|c|}{ PLTS Java-Bali } \\
& & & \multicolumn{3}{|c|}{$\mathbf{8 0 0}$ MW } \\
\cline { 4 - 6 } & & 10,05 & 80 & 40.205 & 96,69 \\
\hline DKI Jakarta & 4,76 & 23,53 & 188 & 94.103 & 234,27 \\
\hline East Java & 11,03 & 2,52 & 20 & 10.097 & 27,72 \\
\hline Bali & 1,18 & 6,93 & 55 & 27.731 & 65,00 \\
\hline Banten & 3,26 & 34,17 & 273 & 136.672 & 300,13 \\
\hline West Java & 16,14 & 20,28 & 162 & 81.112 & 204,30 \\
\hline Central Java & 9,51 & 2,52 & 20 & 10.079 & 24,51 \\
\hline DIY & 1,18 & & & & \\
\hline
\end{tabular}

Based on the Table 3, The largest number of residential customers is West Java of 16.14 million, as many as $34.17 \%$ of the total energy installed in 136.6 homes will produce energy $300.1 \mathrm{GWh}$. While the smallest is DIY and Bali with number of residential customers about 1.18 million, as much as $2.52 \%$ of energy installed in 10,000 homes will generate energy around $24-27 \mathrm{GWh}$.

\subsubsection{Power Sales}

Java-Bali has a different number of customers each city, so the amount of electricity sales also varies. There was number of installation and energy produced by PLTS-PV Rooftop based on the power sales of each province which can be seen in Table 4.

Based on the Table 4, The largest number of power sales is West Java 25,382 GWh, as much as $29.17 \%$ of the total energy installed at 116,681 homes will produce $256.23 \mathrm{GWh}$ of energy. While the smallest is DIY with the number of power sales about 1,763 GWh, as much as $2.06 \%$ of the energy installed in 8,249 homes will produce energy around 20.07.
Table 4. PLTS-PV Rooftop $800 \mathrm{MW}$ based on Power Sales

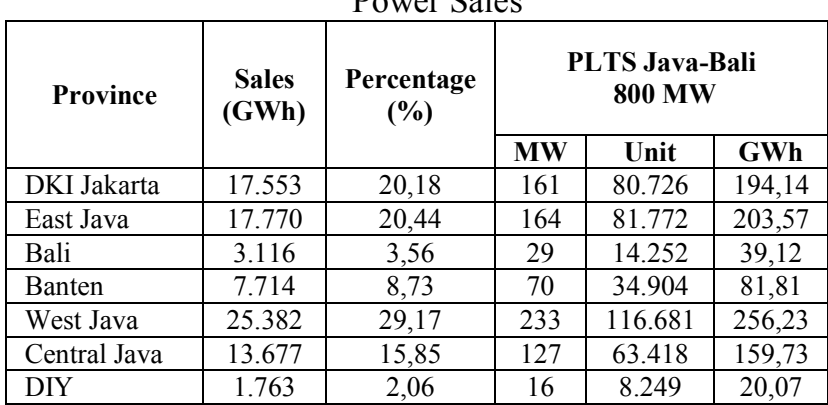

\subsubsection{Number of Population}

There was the number of installation and energy produced by PLTS-PV Rooftop based on the population of each province which can be seen in

Table 5.

Tabel 5. PLTS-PV Rooftop $800 \mathrm{MW}$ based on number of population

\begin{tabular}{|l|c|c|c|c|c|}
\hline \multirow{2}{*}{ Province } & \multirow{2}{*}{$\begin{array}{c}\text { Population } \\
\text { (Million) }\end{array}$} & \multirow{2}{*}{$\begin{array}{c}\text { Percentage } \\
(\%)\end{array}$} & \multicolumn{3}{|c|}{ PLTS Java-Bali } \\
& & & \multicolumn{3}{|c|}{ 800 MW } \\
\cline { 4 - 6 } & & & MW & Atap & GWh \\
\hline DKI Jakarta & 9,61 & 6,84 & 55 & 27.353 & 65,78 \\
\hline East Java & 37,48 & 26,67 & 213 & 106.694 & 265,62 \\
\hline Bali & 3,89 & 2,77 & 22 & 11.077 & 30,41 \\
\hline Banten & 10,63 & 7,57 & 61 & 30.269 & 70,95 \\
\hline West Java & 43,05 & 30,64 & 245 & 122.572 & 269,17 \\
\hline Central Java & 32,38 & 23,05 & 184 & 92.192 & 232,21 \\
\hline DIY & 3,46 & 2,46 & 20 & 9.843 & 23,94 \\
\hline
\end{tabular}

Based on the Table 5, The largest number of population is West Java 43.05 million, as much as $30.64 \%$ of total energy installed in 122,572 homes will produce $269.17 \mathrm{GWh}$ of energy. While the smallest is DIY with population of 3.46 million, as much as $2.46 \%$ of energy installed in 9,843 homes will produce energy about 23.94 GWh.

\subsection{Scenario Analysis}

For scenarios based on income of population, DKI Jakarta has the highest capacity of $458 \mathrm{MW}$. Based on power sales, DKI Jakarta, East Java, West Java, and Central Java have most large capacity. Meanwhile, from the number of residential customers and number of population, the area has a large capacity located in East Java, West Java, and Central Java at 230-300 MW. 


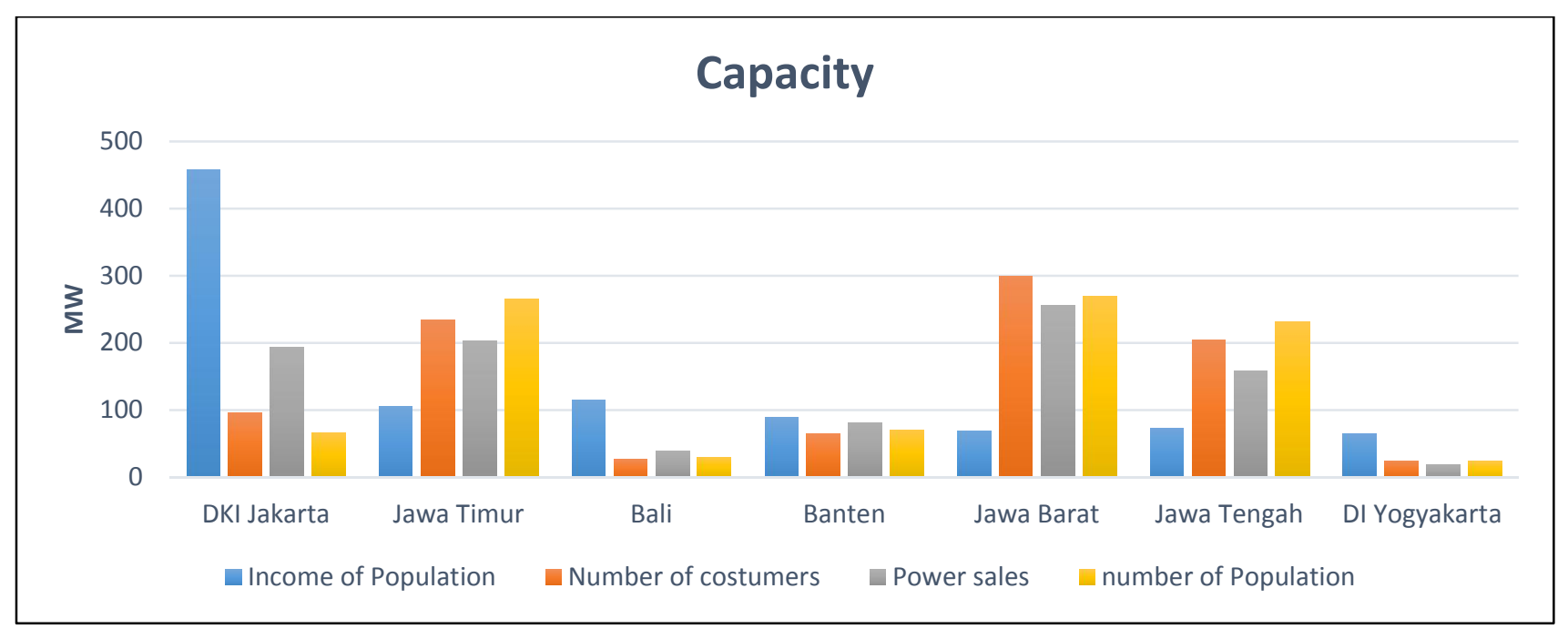

Fig 4. Capacity PLTS Java Bali

\subsection{PLTS Savings}

PLTS PV-Rooftop $2 \mathrm{kWp}$ installed in residence area of Java Bali can minimize the cost by PLN. The savings were seen from the aspect of coal demand as the largest fuel source that produces electrical energy. The electricity savings is calculated by the percentage of energy produced by the PLTS to the residence electrical needs. The percentage is assumed as the value of coal savings so that it can be calculated in rupiah value. With the installation of $800 \mathrm{MW}$ PLTS in 2018, the cost savings can be seen in Fig 5 and 6.

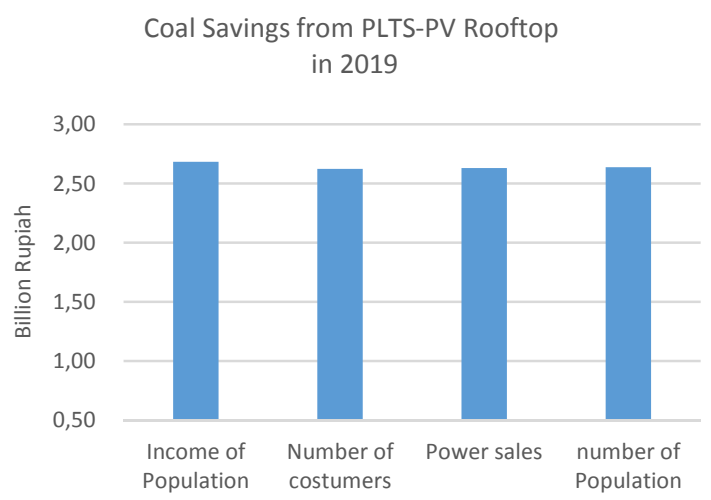

Fig 5. Cost saving PLTS-PV Rooftop $2 \mathrm{kWp}$

Can be seen in the fig 5, in 2019 the biggest savings is 2.68 million earned based on population income. Based on the customer number scenario, savings is 2.62 million; based on total sales, savings is 2.63 million; and by population, savings is 2.64 million.

In the fig $\mathbf{6}$, in the next 9 years, the biggest savings is 11,079 billion earned based on population income. Based on the customer number scenario, savings is 10.825 billion; based on total sales, savings is 10.848 billion; and by population, savings is 10.887 billion

\subsection{Saving PLTS-PV Rooftop of Capacity $1 \mathrm{kWp}-5$ kWp}

When viewed from the difference $\mathrm{kWp}$, the energy savings generated by 1.3 million rupiah for the PLTS with capacity of $1 \mathrm{kWp}$, and energy savings generated by 2.6 million rupiah for PLTS with capacity of 2 $\mathrm{kWp}$. The larger capacity, the greater savings generated by the PLTS. The savings can be seen in fig-7.

Total Coal Savings in 2019-2027

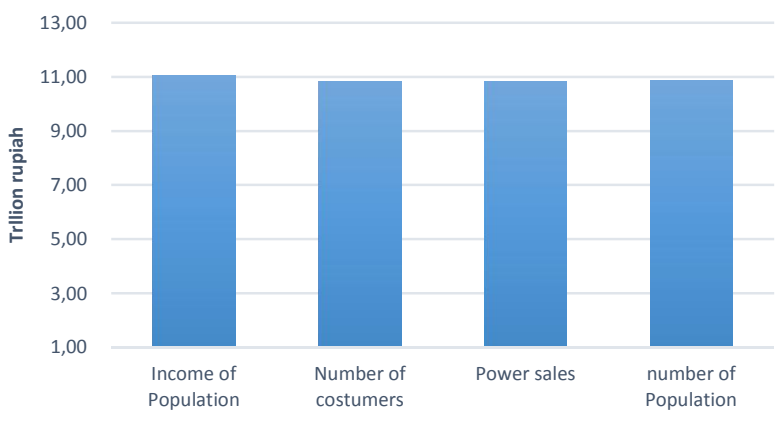

Fig 6. Total saving PLTS 2019-2027

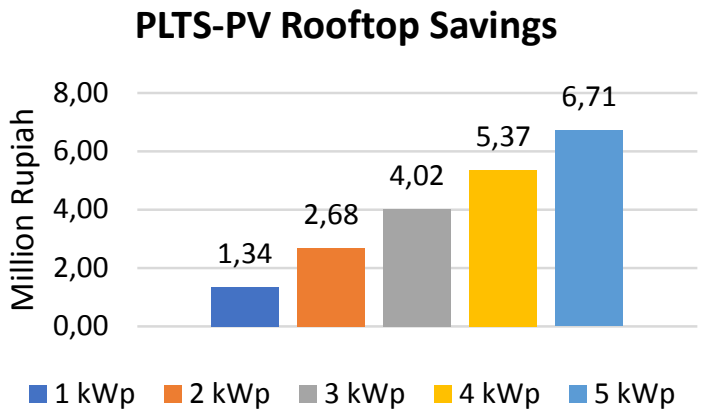

Fig 7. Cost saving PLTS-PV Rooftop capacity of 1 $\mathrm{kWp}-5 \mathrm{kWp}$ 


\subsection{Feasibility Analysis of PLTS-PV Rooftop 2 kWp}

PLTS-PV Rooftop $2 \mathrm{kWp}$ requires considerable investment for every home. Therefore, it takes considerable effort to attract domestic electricity users to participate in using PLTS. The participation of users will help the government program switch to the use of renewable energy succesfull and is also beneficial in reducing user electricity costs. In addition, to increase the interest of the community, it can be considered the type of PV installation with incentives. To assess the feasibility of installing PLTS-PV Rooftop $2 \mathrm{kWp}$, so we doing economic analysis of SAM results area of Jakarta.

Table 6. Economic analysis of the PLTS-PV Rooftop 2 $\mathrm{kWp}$ scheme

\begin{tabular}{|c|c|c|}
\hline Metric & Net Metering & $\begin{array}{c}\text { Net Metering } \\
\text { Incentif }\end{array}$ \\
\hline Net present value & $\$-370$ & $\$ 361$ \\
\hline Payback period & 8,9 years & 6.6 years \\
\hline Incentive & $0 \%$ & $30 \%$ \\
\hline
\end{tabular}

The simulation results of SAM on both payment schemes, it appears that the eligibility of PLTS-PV investment Rooftop $2 \mathrm{kWp}$ is the Net Metering scheme with the incentive from the government. NPV value of \$ 361 or approximately $\mathrm{Rp}$. 5,083,305, with an investment payback period of 6.6 years.

\subsection{Advantage Analysis of PLTS-PV Rooftop 2kWp.}

PLTS-PV Rooftop $2 \mathrm{kWp}$ in the household sector used to save the energy needs of PLN, so that PV system revenue is assessed from the saving of electric energy paid without the system. Figure 8 shows a graph of annual electricity savings about $41.7 \%-37.9 \%$

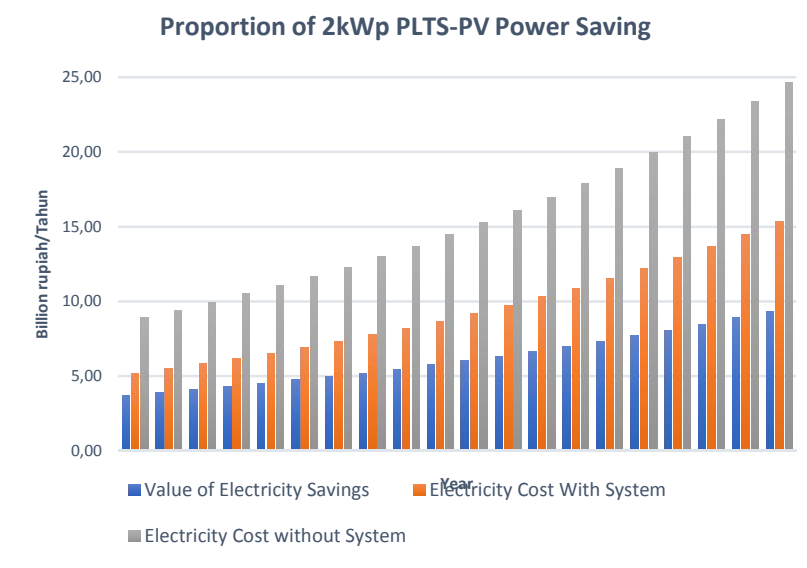

Fig 8. Proportion of electricity savings PLTS-PV Rooftop $2 \mathrm{kWp}$

\section{Conclusion}

PLTS-PV Rooftop $2 \mathrm{kWp}$ planned in the household sector in Java Bali is based on of population income, the number of customers, the number of sales, and the number of population. From the results of the research, it was found that high capacity areas for the development of PLTS are located in DKI Jakarta, West Java, Central Java, and East Java. The area with the highest capacity is DKI Jakarta so that it becomes a reference to analyze the energy saving of electricity. The energy generated by PLTS can replace some of the energy resourced from PLN so as to reduce the need for coal fuel. The savings gained in 2019 of about 2.682.62 million for each home and until 2027 can save about 11.08 trillion rupiah. The Net Metering scheme with incentives of $30 \%$ can be applied to PLTS-PV development of Rooftop $2 \mathrm{kWp}$. With the installation of the household sector in Java Bali can save household electricity payment for $37.9-41,7 \%$.

The Author would like to thank this work was supported and funded by "Hibah Panduan Penelitian Unggulan $\begin{array}{lll}\text { Perguruan } & \text { Tinggi } & \text { (PUPT) }\end{array}$ 491/UN2.R3.1.HKP.05.00/2018““

\section{References}

[1] Nasional, Dewan Energi. (2014). Outlook Energi Indonesia 2014. Jakarta: Kementerian Energi dan Sumber Daya Mineral, RI

[2] Rencana usaha penyediaan tenaga listrik PT PLN (Persero), 2010-2019. (2010). Kebayoran Baru, Jakarta: PT PLN (Persero).

[3] Anangga, Krishadi. 2017. Economic Feasibility Comparison of ON-Grid Residential PV System in 5 cities Across Indonesia. Universitas Indonesia

[4] System Advisor Model (SAM) version 2017.9.5 Help Guide

Meteonorm version 7.1.3.19872 Help Guide

[5] John E. Hanke, Dean Wichiern. 2008. Business Forecasting. United States: pearson international edition

[6] Stephen Cornello. 2016. Cost Competitiveness OF Residential Solar PV: The impact of net metering restrictions. Standford Graduate School OF Bussiness.

[7] Ran Fu, dkk. 2017. U.S. Solar Photovoltaic System Cost Benchmark: Q1 2017. US: National Renewable Energy (NREL). 